University of the Pacific

Scholarly Commons

\title{
A pilot virtual project for advising senior dental hygiene students on work readiness skills
}

Annie Han

University of the Pacific, ahan@pacific.edu

Mustafa S. Radif

University of the Pacific, mradif@pacific.edu

Follow this and additional works at: https://scholarlycommons.pacific.edu/dugoni-facarticles

Part of the Dental Public Health and Education Commons

\section{Recommended Citation}

Han, A., \& Radif, M. S. (2021). A pilot virtual project for advising senior dental hygiene students on work readiness skills. Journal of Dental Education, Online ahead of print, DOI: 10.1002/jdd.12739 https://scholarlycommons.pacific.edu/dugoni-facarticles/521

This Article is brought to you for free and open access by the All Faculty Scholarship at Scholarly Commons. It has been accepted for inclusion in All Dugoni School of Dentistry Faculty Articles by an authorized administrator of Scholarly Commons. For more information, please contact mgibney@pacific.edu. 


\title{
A pilot virtual project for advising senior dental hygiene students on work readiness skills
}

\author{
Annie N. Han EdM ${ }^{1} \quad$ Mustafa S. Radif MA ${ }^{2}$ \\ ${ }^{1}$ Office of Academic Affairs, University of the Pacific, Arthur A. Dugoni School of Dentistry, San Francisco, California, USA \\ ${ }^{2}$ Department of Periodontics, University of the Pacific, Arthur A. Dugoni School of Dentistry, San Francisco, California, USA \\ Correspondence \\ Mustafa S. Radif, MA, University of the Pacific, Arthur A. Dugoni School of Dentistry, 155 Fifth Street, San Francisco, CA 94103, USA. \\ Email:mradif@pacific.edu
}

\section{1 | PROBLEM}

In March 2020, our school transitioned online as per local COVID-19 requirements. Undergraduate Dental Hygiene students $(N=11)$ were undertaking a senior project unit on work readiness skills, including preparation of job application-ready resume and cover letters. By the time of COVID-19 restrictions, students had received a pre-unit anonymous Qualtrics questionnaire measuring workforce experience and resume and cover letter knowledge, followed by an informational seminar about resumes and cover letters-but needed to complete three remaining, sequential activities of a resume and cover letter drafting assignment, advising, and concluding post-unit questionnaire.

Adapting an advising-based unit for a remote online environment brought new considerations, such as accomplishing authentic performance task deliverables through online advising and ensuring adequate time-on-task while guiding learning remotely. Pedagogically, as teaching faculty and staff, we needed to maintain the authentic performance task nature of the resume and cover letter assignment while shifting unit activities online.

Research has shown student enrollment in career course activities has a significant effect on student job search skills and job search self-efficacy. ${ }^{1}$ Teaching job search skills more than doubles job seekers' odds of obtaining employment. ${ }^{2}$ Especially relevant to remote higher education during COVID-19, four evidence-based strategies promote success in virtual advising: encouraging goal setting, promoting plan-making, eliminating hassles, and helping students manage attention. ${ }^{3}$ Exist-
TA B LE 1 Students' perceived usefulness of required resume and cover letter preparation activities toward gaining job application confidence

\begin{tabular}{|lll|}
$\begin{array}{l}\text { Resume and cover letter } \\
\text { preparation activity }\end{array}$ & $\begin{array}{l}\text { Very } \\
\text { useful } \\
(\boldsymbol{n}=\mathbf{9 , \% )}\end{array}$ & $\begin{array}{l}\text { Somewhat } \\
\text { useful } \\
(\boldsymbol{n}=\mathbf{9 , \% )}\end{array}$ \\
\hline Informational seminar and Q\&A & $5(56 \%)$ & $4(44 \%)$ \\
\hline Assignment drafting on Google Docs & $4(44 \%)$ & $5(56 \%)$ \\
\hline Advising/suggestions on Google Docs & $8(89 \%)$ & $1(11 \%)$ \\
\hline
\end{tabular}

ing research looking at online courses with authentic design/development learning tasks measuring students' time-on-task, behavioral experiences, and performance found students received higher performance scores at mid and end of semester, along with higher overall performance scores than peers receiving solely discussion-based activities. $^{4}$

\section{2 | SOLUTION}

In lieu of in-person resume and cover letter drafting and advising, we used Google Docs to replicate the authentic performance task of real-time drafting and advising: tracking document history, real-time feedback and corrections, and targeting document areas meriting further work and feedback. A generic resume and cover letter template was developed, assigned, and shared with each student through a secure Google Docs link. Students then read and drafted, and staff provided feedback through the suggesting feature. To ensure adequate time-on-task remotely, 
each student's assignment edits and staff feedback were tracked through Google Docs' timestamps. Using Google Docs helped students accomplish the resume and cover letter assignment despite being remote. The staff provided Zoom video advising, optional based on students' needs, ability to connect outside of class time, and early comfort with Zoom. Finally, students answered post-assignment questionnaires about required project activities' usefulness toward gaining job application confidence. This study was approved by the university's Institutional Review Board (\# 2021-24).

\section{3 | RESULTS}

All students $(N=11)$ completed the five-part resume and cover letter unit in full. Results of the post-unit questionnaire showed all students (11 of 11 students) felt very confident or somewhat confident to apply for jobs with a resume and cover letter, compared with pre-unit questionnaire results of feeling somewhat confident about applying for jobs with a resume and cover letter (five of 11 students), unsure about applying with a resume and cover letter (four of 11 students) or definitely needing help applying with a resume and cover letter (two of 11 students).

When surveyed in the post-unit questionnaire about usefulness of the unit's required activities, eight of nine students responded that the advising and suggestions activity completed through Google Docs' comments/ suggestions feature was very useful toward gaining confidence to apply for jobs (Table 1). Two of the 11 program students did not provide a response to this post-unit questionnaire item. All students (11 of 11 students) attributed the unit's activities with gaining more confidence in applying to jobs with a prepared resume and cover letter. A limitation was the small number of students (three of 11 students) who participated in the final optional Zoom advising during this pilot unit, which took place during the early days of the COVID-19 shelter-in-place orders. Piloting this educational unit with a small cohort allowed us to explore possibilities of scaling it to a future selective course with a larger cohort.

One year following the 11 senior students' graduation from the Dental Hygiene program, a voluntary postgraduation job outcomes survey was administered. Nine of the 11 students responded to the job outcomes survey and two students did not return survey responses. Job outcomes survey results showed all nine survey respondents had proceeded to job placement exploration following graduation. Eight of nine respondents reported successful job placement within a year of graduation. Eight of nine respondents reported having applied to jobs using the job application documents developed during the Google
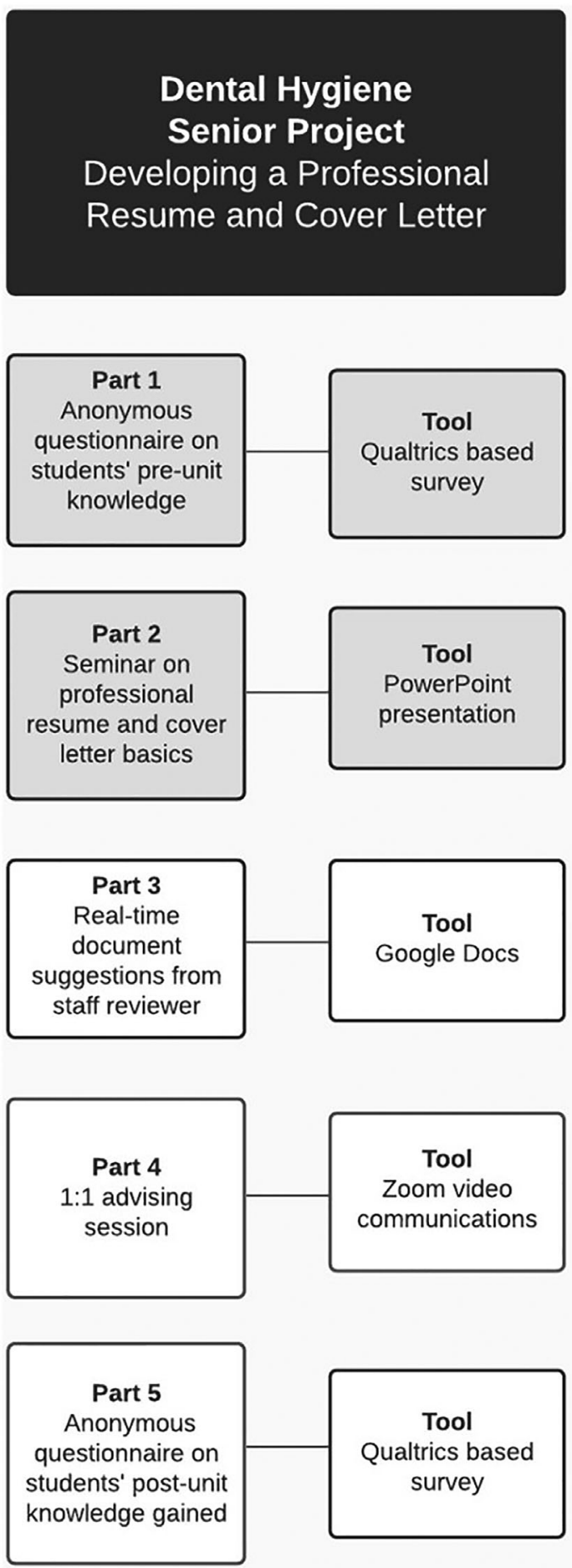

In person

Remote

F I G URE 1 Concept map of the five-part educational unit on preparing students for job search readiness. Each part of the project can be delivered using an online or electronic tool for remote teaching settings 
Docs-based authentic performance task. Additionally, eight of nine respondents agreed that the resume and cover letter unit's activities had helped them land the job(s) they were seeking. This educational unit could be similarly delivered in other remote hybrid or online work readiness skills training settings (Figure 1).

\section{REFERENCES}

1. McDow LW., Zabrucky KM. Effectiveness of a career development course on students' job search skills and self-efficacy. J Coll Stud Dev. 2015;56(6):632-636. https://doi.org/10.1353/csd. 2015.0058.

2. Liu S, Huang JL, Wang M. Effectiveness of job search interventions: A meta-analytic review. Psychol Bull. 2014;140(4): 1009-1041. http://doi.org/10.1037/a0035923.
3. University of Virginia. Evidence Based Strategies for Successful Remote Advising. Nudge4 Projects. Charlottesville, Virginia: University of Virginia; 2021. https://nudge4.org/nudge4-projects/ remoteadvising/.

4. Park S. Analysis of time-on-task, behavior experiences, and performance in two online courses with different authentic learning tasks. Int Rev Res Open Distrib Learn. 2017;18:213-233. https:// doi.org/10.19173/irrodl.v18i2.2433.

How to cite this article: Han AN, Radif MS. A pilot virtual project for advising senior dental hygiene students on work readiness skills. J Dent Educ. 2021;1-3. https://doi.org/10.1002/jdd.12739 